\title{
FORAGE YIELD AND SOME QUALITY TRAITS OF PERSIAN CLOVER AT WINTER AND SPRING SOWING UNDER EDIRNE ECOLOGICAL CONDITIONS, TURKEY
}

\author{
Cengiz Kucukduvan ${ }^{1}$, Ertan Ates ${ }^{2, *}$ \\ ${ }^{1}$ The Chamber of Edirne Agriculture, Edirne, Turkey \\ ${ }^{2}$ Tekirdag Namik Kemal University, Agriculture Faculty, Field Crops Department, 59030 Tekirdag, Turkey
}

\begin{abstract}
The research was carried out to determine the forage yield and some quality properties of Persian clover (Trifolium resupinatum L. ssp. majus Boiss.) at different sowing times (winter and spring) under Edirne ecological conditions, Turkey. The study was conducted during 2015-2016 at Degirmenyeni village of the Edirne province in Thrace, Turkey. Experiments were planted in randomized block design with three replications. The different sowing times affected the plant height, stem diameter, number of leaves per main stem, number of branches per plant, leaf length and leaflet length. The effect of sowing times on the leaflet width was not significant. Higher herbage $\left(29.92 t\right.$ ha $\left.{ }^{-1}\right)$ and hay $(7.05 t$ $\mathrm{ha}^{-1}$ ) yields were obtained from spring sowing. The crude protein, crude fiber, neutral detergent fiber, acid detergent fiber, potassium, calcium, magnesium and phosphorus contents ranged from 20.03-20.14, 20.87-20.96, 40.42, 29.7729.93, 1.45-1.46, 1.29-1.30, 0.48-0.49 and 0.41-0.42 \%, respectively in Persian clover at different sowing times.
\end{abstract}

Keywords: forage quality, forage yield, Persian clover, Trifolium resupinatum L.

\section{INTRODUCTION}

A wide range of crops in addition to annual, biennial and perennial grasses and legumes can be used as forage crops. Clovers are in the tribe Trifolieae of the subfamily Papilionoideae, family Fabaceae, Trifolium L. The genus contains approximately 250-300 species. Clover species are herbaceous annuals, perennials, often prostrate, and rarely more than $100 \mathrm{~cm}$ tall. Persian clover $(T$. resupinatum L.) and Persian clover-annual grasses mixtures are commonly used for herbage, hay and grazing in the Mediterranean region and in temperate areas of world. It is a semi-erect annual legume, that is reseeded as winter forage crop and can survive at $-18{ }^{\circ} \mathrm{C}$ under the snow (Ates, 2013). There are three main subspecies of Persian clover: ssp. majus Boiss., ssp. typicum Fiori et Paol. and ssp. resupinatum Gib. These are a native of western Asia, central and southern Europe, Mediterranean countries. Originating in Anatolia and northern Iran, it was cultivated for forage during the $18^{\text {th }}$ century in Italy and France (Tekeli and Ates, 2011). Persian clover is adapted to a wide range of soil types, but it is best suited for low-lying areas with well-drained, clay-loam and airy textured soils of $\mathrm{pH}$ from 5 to 8 (Hoveland and Evers, 1995; Ate and Servet, 2004; Ates and Tekeli, 2007). It has been successfully grown in areas that receive between 450 and $600 \mathrm{~mm}$ annual rainfall (Ates and Tekeli, 2001). It is sown for hay, green manure and seed production. 
Nevertheless, Persian clover has been used as a self-regenerating pasture in irrigated and dry land situations, often in mixtures with subterranean clover ( $T$. subterraneum L.), to extend spring production following subterranean clover senescence. It also has the role of being soil renovator following land forming (Lacy et al., 2003; Ate and Servet, 2004). The high feeding value and various roles of Persian clover in Mediterranean countries, southern Australia and America have been outlined by Stockdale (1993), Lee et al. (1999) and Ate and Servet (2004). High quality forage may be obtained from Persian clover cut at all the growing stages (Tekeli et al., 2003).

The yield and quality of forage crops are highly influenced by genotype and environment interaction (Ates and Tekeli, 2004). These are the result of the interaction between a genotype's potential expression and the environment, which is modified by agronomic management in order to meet to objectives of the farmer (Mariani and Ferrante, 2017; Golla et al., 2018). Therefore, much breeding and agronomic research has been designed to improve performance of forage crops under various agro climate conditions (Tenikecier and Ates, 2020). Sowing time is one of the essential factors that strongly affect forage crops production in rainfed agriculture. Particularly in many parts of World where the rainy season starts with some light showers followed by dry spells, can cause poor forage crops emergence or desiccate a young plant. Abnormally low and infrequent rainfall has been increasing the frequency and impact of droughts. So it is important to adjust planting time to reduce such impacts (Golla et al., 2018). Besides, appropriate sowing time could make full use of thermal resources before winter, cultivate strong seedling, and improve the population quality as well as herbage or hay yield of cool season forage legumes and grasses. However, feasible early springtime sowing can inhibit vegetative growth and reduce soil water consumption, which will cut down irrigation water in regions where irrigation is required. But, early spring sowing can decrease herbage or hay yield of temperate forage crops. The hypothesis of this research was to evaluate the impact of winter and springtime sowing on the forage yield and some quality properties of Persian clover (T. resupinatum ssp. majus Boiss.) under Edirne ecological conditions of Turkey.

\section{MATERIALS AND METHODS}

The study was carried out in 2015-2016 on sandy loam soil with $\mathrm{pH} 5.5$ on the farm land of Degirmenyeri-Edirne in Turkey located at $41^{\circ} 46^{\prime} 25,48^{\prime \prime} \mathrm{N}, 26^{\circ} 34^{\prime} 37,45^{\prime \prime} \mathrm{E}$, about $74 \mathrm{~m}$ altitude sea level, with a typical subtropical climate. The total rainfall of this area is $593.2 \mathrm{~mm}$ and average temperature is $9.1^{\circ} \mathrm{C}$.

The experiment was laid out in a randomized complete block design, with three replications. At each sowing time, a basal fertilizer containing $\mathrm{N}\left(50 \mathrm{~kg} \mathrm{ha}^{-1}\right)$ was incorporated into the soil at the time of land preparation. The seeds of Persian clover cultivar (Demet-82) were sown on October $7^{\text {th }}$, 2015 and on March 12 $2^{\text {th }}, 2016$. Each plot consisted of 10 rows with a length of $5 \mathrm{~m}$. Row distance of $25 \mathrm{~cm}$ and sowing rate of $20 \mathrm{~kg} \mathrm{ha}^{-1}$ were used (Celen, 2009). The plots were not irrigated and after they were sown and harvested. Plant height $(\mathrm{cm})$, number of branches per plant and number of leaves per main stem were determined in ten plants, which were randomly chosen from all plots (Ates and Tekeli, 2001). The stem diameter $(\mathrm{mm})$ was measured between the third and fourth node. Leaf length $(\mathrm{cm})$, leaflet length $(\mathrm{cm})$ and leaflet width $(\mathrm{mm})$ were measured on the leaf at the third node of the plants (Tekeli and Ates, 2003; Ate and Servet, 2004). One cut (in $2 \mathrm{~m}^{2}$ quadrates) was made for each sowing time at the full-bloom stage (for first sowing time: May 29, for second sowing time: $19 \mathrm{July})$ at $5 \mathrm{~cm}$ height form ground level. Then, herbage yield ( $\left.\mathrm{t} \mathrm{ha}^{-1}\right)$ was calculated (Mut et al., 2017). Hay yield ( $\mathrm{t} \mathrm{ha}^{-1}$ ) for those samples were calculated by drying approximately 500 
g samples at $55{ }^{\circ} \mathrm{C}$ for 48 hour followed by storage for a further day at room temperature (Ates and Tekeli, 2007).

Dry hay samples were ground to small $(\leq 1 \mathrm{~mm})$ pieces and used for the analyses (Tenikecier and Ates, 2019; Atalay and Ates, 2020). The samples were analyzed for $\mathrm{N}$ using procedures of the Association of Official Analytical Chemists (AOAC, 2019). Crude protein (CP) content (\%) of the samples were calculated by multiplying $\mathrm{N}$ contents by a coefficient of 6.25 . The crude fiber (CF), acid detergent fiber (ADF) and neutral detergent fiber (NDF) contents (\%) were determined by Weende and Van Soest methods (Goering and Van Soest, 1970; AOAC, 2019). Potassium (K), calcium $(\mathrm{Ca})$ and magnesium $(\mathrm{Mg})$ contents $(\%)$ were determined using an atomic absorption spectrophotometer. The samples were wet-fired with nitric-perchloric acid, and phosphorus $(\mathrm{P})$ content (\%) was found spectrophotometrically. All samples were analyzed in duplicate. All data were analyzed statistically by analysis of variance using TOTEM-STAT software (Acikgoz et al., 2004).

\section{RESULTS AND DISCUSSIONS}

The different sowing times affected the plant height, stem diameter, number of leaves per main stem, number of branches per plant, leaf length and leaflet length (Figure 1). The effect of sowing times on the leaflet width (26.03-26.04 mm) was not significant $(\mathrm{P}>0.05)$.

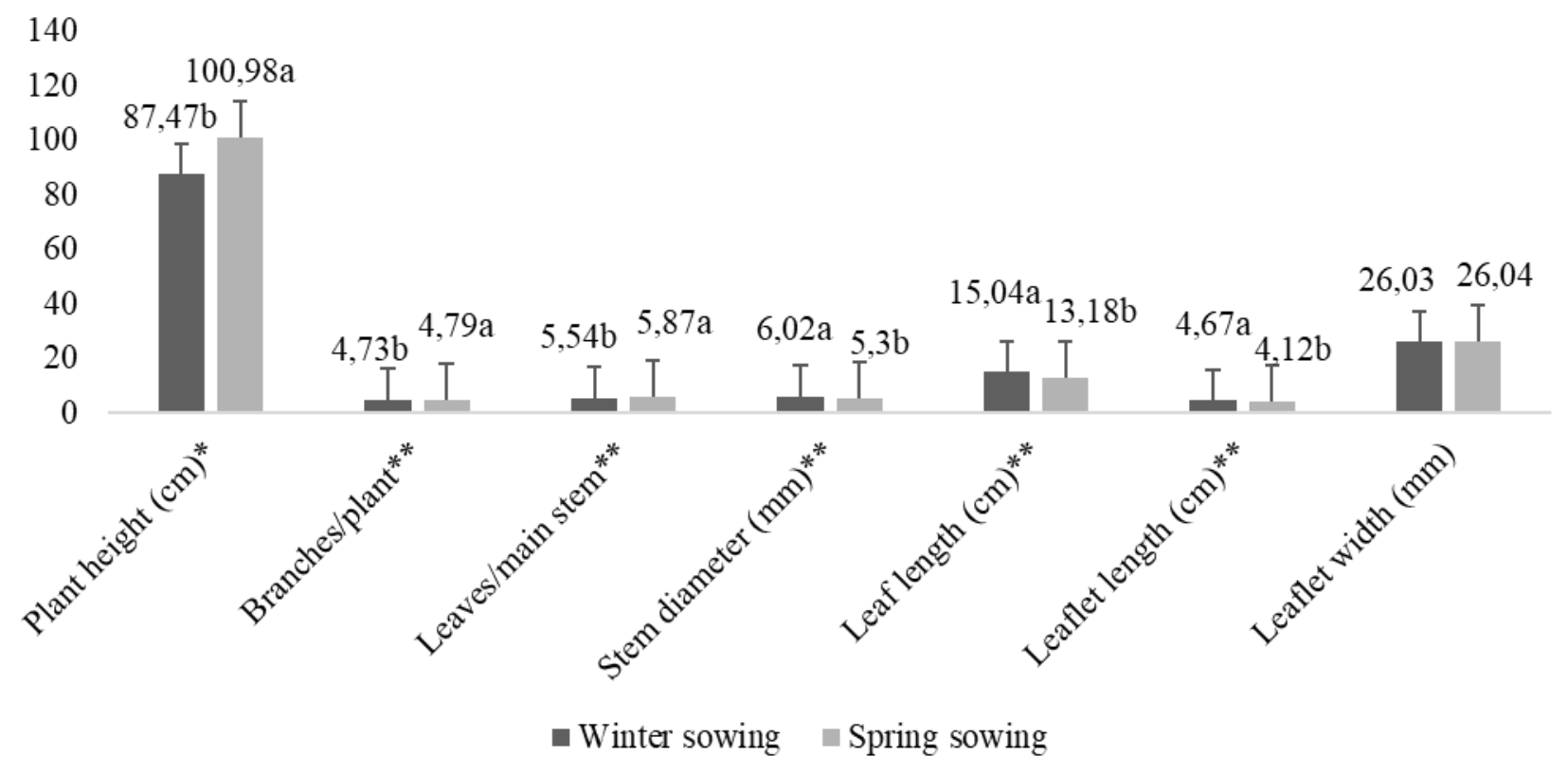

Figure 1. Some morphological characters of Persian clover at different sowing times, *: $P<0.05, * *: P<0.01$

Spring sowing significantly increased plant height $(100.98 \mathrm{~cm})$, number of branches per plant (4.79) and number of leaves per main stem (5.87) compared to winter sowing. However, the stem diameter $(6.02 \mathrm{~mm})$, leaf length $15.04 \mathrm{~cm})$ and leaflet length $(4.4 .67 \mathrm{~cm})$ increased depending on the winter sowing. The plant height, main stem length, number of branches per plant, number of leaves per plant, leaf length, leaf weight, main stem diameter, leaflet length and leaflet width are important characters used to determine herbage and hay yields (Ate and Servet, 2004; Ates and Tenikecier, 


\begin{tabular}{lr}
\hline & $\begin{array}{c}\text { Current Trends in Natural Sciences } \\
\text { Vol. 10, Issue 19, pp. 113-120, 2021 } \\
\text { https://doi.org/10.47068/ctns.2021.v10i19.015 }\end{array}$ \\
\cline { 2 - 3 } $\begin{array}{l}\text { Current Trends in Natural Sciences (on-line) } \\
\text { ISSN: 2284-953X }\end{array}$ & Current Trends in Natural Sciences (CD-Rom) \\
ISSN-L: 2284-9521 & ISSN: 2284-9521 \\
\hline
\end{tabular}

2019); besides, leaf length, leaf weight, main stem diameter, leaflet length and width, leaf/stem ratio, protein, fiber and mineral contents are important traits for forage quality (Ates, 2011; Tenikecier and Orak, 2020). Acar et al. (2001) reported 2-5 stem per plant from hare's-food clover (T. arvense L.). Bennett (1998), Tekeli and Ates (2002) and Edincliler et al. (2004) obtained measurements of leaflet length between 1.0 and $4.5 \mathrm{~cm}$ in Persian clover. Tekeli et al. (2003) and Ate and Servet (2004) emphasized that the plant height changed from 60.19 to $115.60 \mathrm{~cm}$ at maturity stage; whereas Lee et al. (1999) reported that plant grows to $20-60 \mathrm{~cm}$. Ate and Servet (2004) found a main stem diameter of 7.81-8.70 mm, a number of leaves per main stem of 6.6313.23 , a leaf length of 34.44-34.99 cm, a leaflet width of 3.34-3.52 cm and a leaflet length of 4.89$5.54 \mathrm{~cm}$ for Persian clover. Tekeli and Ates (2006) stated that the leaflet width varied 0.5 to $3.0 \mathrm{~cm}$ in alsike clover (T. hybridum L.). The lowest plant height $(50 \mathrm{~cm})$ of zigzag clover (T. medium L.) was measured by Stace et al. (2010). The results were similar to those reported by these researchers. The effect of sowing times on the herbage and hay yields were found to be significant $(\mathrm{P}<0.05)$, whereas the $\mathrm{CP}, \mathrm{CF}, \mathrm{NDF}$ and ADF contents were not influenced by sowing times (Figure 2). Higher herbage $\left(29.92 \mathrm{t} \mathrm{ha}^{-1}\right)$ and hay $\left(7.05 \mathrm{t} \mathrm{ha}^{-1}\right)$ yields were obtained from spring sowing. The $\mathrm{CP}, \mathrm{CF}, \mathrm{NDF}$ and ADF contents ranged from 20.03-20.14 \%, 20.87-20.96 \%, $40.42 \%$ and 29.77 to $29.93 \%$, respectively in Persian clover at different sowing times.

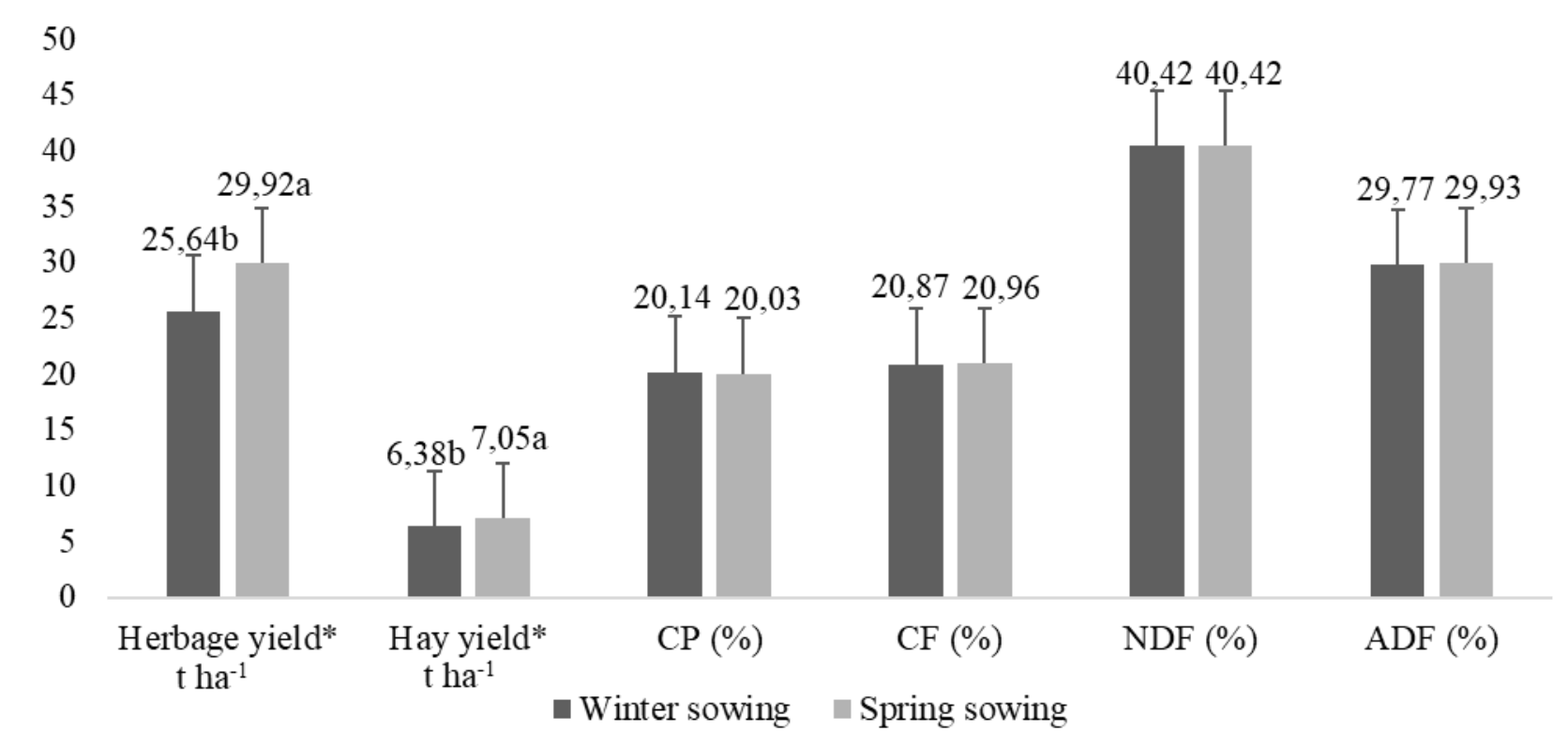

Figure 2. Forage yield and some quality traits of Persian clover at different sowing times, *: P<0.05

The protein and fiber contents of forage crops can be quite variable among species and their genotypes. However, a forage quality property of forage legumes and grasses varies with different ecological conditions of locations, agronomic management, soil traits and growth stages. Generally, forage legumes typically contain higher protein levels (12-26\%) compared with grasses (8-22\%). Tenikecier and Ates (2018) stated that the crude protein content and fractionation varied depending on the forage crop species or varieties and agronomic management. With forages, however, leaves and stems quality begin to decline early in the growth cycle due to deposition and lignification of NDF especially in stems (Moore et al., 2007; Ates, 2011). Forage grasses are higher in NDF, ADF and ADL at a given stage of growth than forage legumes. The quality of forage crops is best 


\begin{tabular}{lr}
\hline & $\begin{array}{c}\text { Current Trends in Natural Sciences } \\
\text { Vol. 10, Issue 19, pp. 113-120, 2021 } \\
\text { https://doi.org/10.47068/ctns.2021.v10i19.015 }\end{array}$ \\
\cline { 2 - 3 } $\begin{array}{l}\text { Current Trends in Natural Sciences (on-line) } \\
\text { ISSN: 2284-953X }\end{array}$ & Current Trends in Natural Sciences (CD-Rom) \\
ISSN-L: 2284-9521 & ISSN: 2284-9521 \\
\hline
\end{tabular}

estimated by their potential dry matter (DM) intake and DM digestibility, which are determined by the NDF and ADF fractions, respectively. Both NDF and ADF increase as the plant matures causing a decline in the quality of the forage (Linn and Kuehn, 1997; Ates and Tenikecier, 2019). NDF varies from roughly $10 \%$ in corn grain, which is nearly $90 \%$ digestible, to approximately 80 $\%$ in straws and tropical grasses, which generally ranged from 20 to $50 \%$ in digestibility. ADF ranges from approximately $3 \%$ in corn grain to $40 \%$ in mature forages and $50 \%$ in straws. ADF values are slightly higher than are those for CF because all the lignin and some ash are included in the former (Fisher et al., 1995). Acikgoz (2001) and Tekeli and Ates (2002) pointed out that Persian clover provides 20.0-74.31 t ha ${ }^{-1}$ of herbage yield under dry and irrigation conditions. Alford et al. (2003) investigated intercropping irrigated corn with annual legumes for fall forage in the high plains and obtained lower value for CP (13.5\%), higher values for ADF (45.8 \%) and NDF (56.1 $\%$ ). Tekeli et al. (2003), Ate and Servet (2004) and Tekeli and Ates (2006) found a CP of 15.01$24.4 \%$ and a CF of 11.2-21.2\% for Persian clover. Celen et al. (2006) reported the highest herbage yield of Persian clover was 83.90-98.50 t ha-1 for the $20 \mathrm{~cm}$ row distance. The results of herbage yield were lower than those reported by these researchers.

The means of the mineral contents from the sowing times are not significantly different by a LSD test at the $\mathrm{P}=0.05$ level of probability (Figure 3 ). The $\mathrm{K}, \mathrm{Ca}, \mathrm{Mg}$ and $\mathrm{P}$ contents ranged from 1.45$1.46,1.29-1.30,0.48-0.49$ and $0.41-0.42 \%$, respectively in Persian clover at different sowing times.

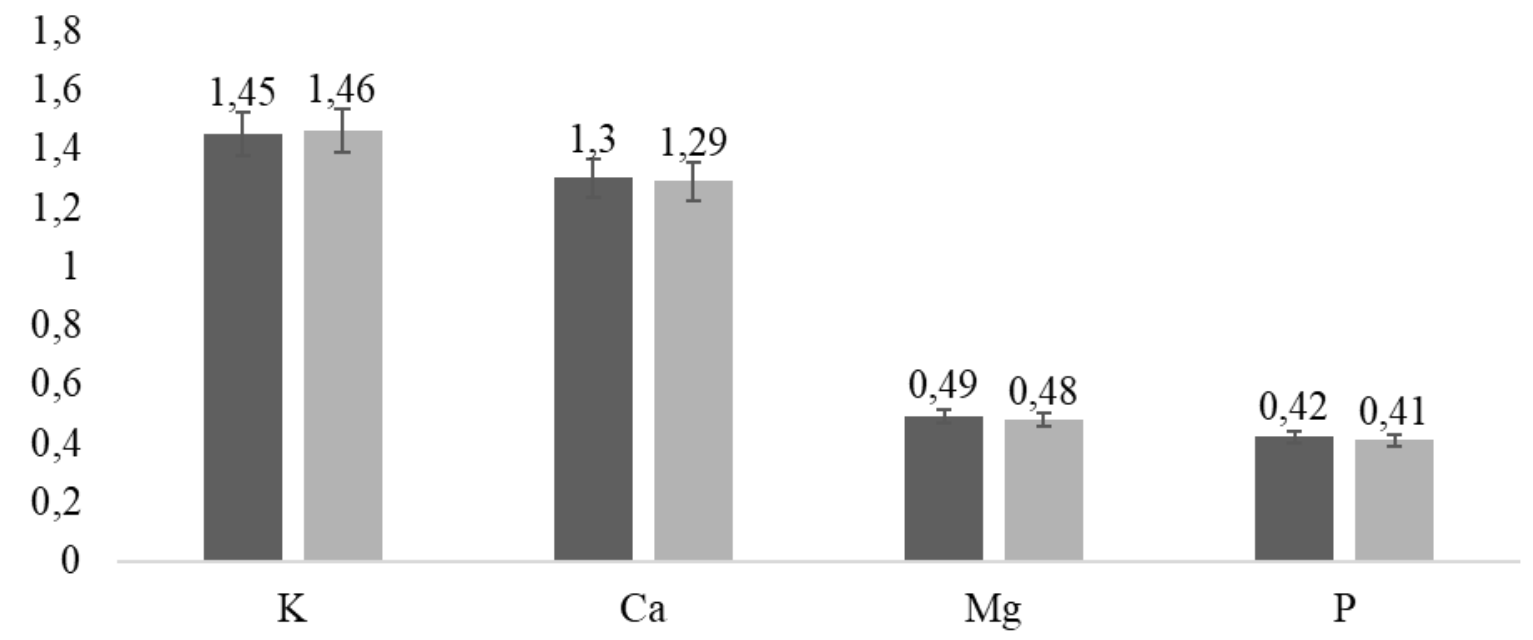

- Winter sowing $\quad$ Spring sowing

Figure 3. Mineral contents (\% DM) of Persian clover at different sowing times

Forage crops mature partly in response to internal factors inherent in their genetic makeup and partly in response to external factors, either natural (season, climate etc.) or cultivation techniques (irrigation, fertilization etc.), and there are associated changes in mineral composition (Suttle, 2010). Forage legumes are generally much richer in minerals than forage grasses growing in comparable conditions, whether temperate or tropical climates. The mineral elements play a very important role in the growth of plants and animals. They are very important to keep this balance; even though one element may be at the minimum, the other element may be in excess of the balance, consequently creating an imbalance within the animal's body (Miller and Reetz-Jr, 1995). Required amounts of minerals are the most precise, but they can vary with total feed intake (e.g., 
those for calcium and phosphorus for ruminants) (AFRC, 1991; Suttle, 2010). For example, The $\mathrm{Ca} / \mathrm{P}$ ratio in Persian clover (3:1) is higher than the $2: 1$ ratio recommended for livestock feeds. Thus, Persian clover has the potential to produce a $\mathrm{Ca} / \mathrm{P}$ imbalance (Tekeli and Ates, 2006). Besides, a 200-kg horse gaining $1 \mathrm{~kg} \mathrm{day}^{-1}$ has been estimated by factorial modelling to require only $0.7 \mathrm{~g} \mathrm{Mg} \mathrm{kg}^{-1} \mathrm{DM}$ in its pasture, while lactating mares require $1.7 \mathrm{~g} \mathrm{Mg} \mathrm{kg}^{-1} \mathrm{DM}$ (Grace et al., 2002a; b). A lower P content of $0.31 \%$ was found by Essig (1985), whereas Tekeli et al. (2003), Ate and Servet (2004), Tekeli and Ates (2006) reported 0.24-0.51\% P from Persian clover, similar to the present findings. Lanyon and Smith (1985) and Robinson (1985) found a K of $10 \mathrm{~g} \mathrm{~kg}^{-1} \mathrm{DM}$ for white clover (T. repens L.) and strawberry clover (T. fragiferum L.). Minson (1990) pointed out that grasses in temperate and tropical pastures contain on average 1.8 and $3.6 \mathrm{~g} \mathrm{Mg} \mathrm{kg}^{-1} \mathrm{DM}$, respectively, and legumes 2.6 and $2.8 \mathrm{~g} \mathrm{Mg} \mathrm{kg}^{-1} \mathrm{DM}$, respectively. NRC (2001) has placed the tolerable limits of $\mathrm{Mg}$ for pigs, poultry, ruminants and horses at 2.4, 5.0-7.5, 6 and $8 \mathrm{~g} \mathrm{~kg}^{-1} \mathrm{DM}$, respectively. Suttle (2010) emphasized that the K contents in forages are highly variable.

\section{CONCLUSIONS}

From the results, Persian clover was showed equal superiority of some quality traits at winter and spring sowing under Edirne ecological conditions in Turkey, but in terms of herbage and hay yields, spring sowing is better. Therefore, Persian clover can be sown at springtime to obtain maximum forage yield in similar ecological regions at dry land condition. Besides, crude protein, fiber and mineral contents of its generally adequate to meet the needs of ruminants.

\section{ACKNOWLEDGEMENT}

This article is a part of MSc thesis and special thanks to our Institute of Natural and Applied Sciences, Tekirdag Namik Kemal University, Turkey for kind support and providing the facilities.

\section{REFERENCES}

Acar, Z., Ayan, I., Gulser, C. (2001). Some morphological and nutritional properties of legumes under natural conditions. Pakistan J Biol Sci, 4, 1312-1315.

Acikgoz, E. (2001). Yem Bitkileri [Forage Crops]. Uludag Universitesi Guclendirme Vakfi Yayin No: 182, VIPAS AS Yayin No: 85, Bursa, Turkey.

Acikgoz, N., Ilker, E., Gocgel, A. (2004). Biyolojik Araştırmaların Bilgisayarda Değerlendirilmeleri [Assessment of Biological Research on The Computer]. EU TOTEM Yayin No. 2, Izmir, Turkey.

AFRC. (1991). Technical Committee on Responses to Nutrients Report No. 6. A reappraisal of the calcium and phosphorus requirements of sheep and cattle. Nutrition Abstracts and Reviews, 61, 573-612.

Alford, C.M., Krall, J.M., Miller, S.D. (2003). Intercropping irrigated corn with annual legumes for fall forage in the high plains. Agronomy Journal, 95, 520-525.

AOAC. (2019). Official Methods of Analysis of AOAC International. 21 ${ }^{\text {st }} \mathrm{Ed}$, Association of Official Analytical Chemists, USA.

Atalay, M., Ates, E. (2020). Effect of different nitrogen doses on yield and some quality properties in sorghum x Sudan grass hybrid (Sorghum bicolor (L.) Moench x Sorghum sudanense (Piper) Stapf) cultivars under Edirne ecological conditions. BSEU J Sci, 7, 221-230.

Ate, E., Servet, A. (2004). Effects of row distances and cutting dates on herb yield and some morphological characters of Persian clover (Trifolium resupinatum L.). Cuban J Agric Sci, 38, 317-321.

Ates, E. (2011). Determination of forage yield and its components in blue melilot (Melilotus caerulea (L.) Desr.) grown in the western region of Turkey. Cuban J Agric Sci, 45, 299-302.

Ates, E. (2013). Iran Ucgulu [Persian Clover]. Hasad Hayvancilik, 29 (339), 56-58.

Ates, E., Tekeli, A.S. (2001). Comparison of yield components cultivated and wild Persian clovers (Trifolium resupinatum L.). Proceedings of $4^{\text {th }}$ Turkey Field Crops Congress, 17-21 Sept., Tekirdag, Turkey, pp 67-73. 


\section{Current Trends in Natural Sciences}

Vol. 10, Issue 19, pp. 113-120, 2021

https://doi.org/10.47068/ctns.2021.v10i19.015

Current Trends in Natural Sciences (on-line)

ISSN: 2284-953X

Current Trends in Natural Sciences (CD-Rom)

ISSN: 2284-9521

ISSN-L: 2284-9521

ISSN-L: 2284-9521

Ates, E., Tekeli, A.S. (2004). Assessing heritability and variance components of agronomic traits of four alfalfa (Medicago sativa L.) cultivars. Acta Agr Hung, 52, 263-268.

Ates, E., Tekeli, A.S. (2007). Salinity tolerance of Persian clover (Trifolium resupinatum L. var. majus Boiss.) lines at germination and seedling stages. World J Agric Sci, 3,71-79.

Ates, E., Tenikecier, H.S. (2019). Hydrocyanic acid content, forage yield and some quality features of two sorghumSudan grass hybrid cultivars under different nitrogen doses in Thrace, Turkey. Current Trends in Natural Sciences, 8, 55-62.

Bennett, S.J. (1998). Genetic variation in Trifolium: Comparison of some outcrossing and inbreeding species from Turkey. Retrieved March 15, 2021, from http://agronomyaustraliaproceedings.org/images/ sampledata/1998/1/294bennett.pdf

Celen, A.E. (2009). Acem Üçgülü [Persian Clover] (Trifolium resupinatum L.). In: Avcioglu R, Hatipoglu R, Karadag Y (eds), Yembitkileri, Baklagil Yem Bitkileri Vol. 2, T.C. Tarim ve Koyisleri Bakanligi Tarimsal Uretim ve Gelistirme Genel Mudurlugu, T.C. Tarim ve Koyisleri Bakanligi Yayinlari, Izmir, Turkey, pp 369-375.

Celen, A.E., Avcioglu, R., Geren, H., Uzun, A. (2006). Herbage yield of Persian clover (Trifolium resupinatum L.) as affected by row distance and herbicide application. Crop Protec, 25, 496-500.

Edincliler, N., Nemli, Y., Kaya, I. (2004). Diagnosis of weed species of some genus Trifolium in wheat fields in Izmir and its environment. Y.Y.U. Zir Fak Tar Bil Derg, 14, 85-93.

Essig, H.W. (1985). Quality and antiquality components. In: Taylor NL (ed), Clover Science and Technology, ASA/CSSA/SSSA, South Segue Road, Madison, Wisconsin, USA, p 309.

Fisher, D.S., Burns, J.C., Moore, J.E. (1995). The nutritive evaluation of forage. In: Barnes RF, Miller DA, Nelson JC (eds), Forages. Volume I. An introduction to grassland agriculture, Iowa State University Press, Iowa, USA.

Goering, H.K., Van Soest, P.J. (1970). Forage Fiber Analysis: Apparatus, Reagents, Procedures and Some Applications. Agric. Handbook No. 379. ARC, USDA, Washington DC, USA.

Golla, B., Tadesse, B., Chalsisa, D., Bayisa, E. (2018). Effect of sowing time and environmental variation on yield of different maize. Open J Plant Sci, 3, 41-45.

Grace, N.D., Shaw, H.L., Firth, E.C., Gee, E.K. (2002a). Determination of digestible energy intake, and apparent absorption of macroelements of grazing, lactating Thoroughbred mares. New Zealand Veterinary Journal, 50 , 182-185.

Grace, N.D., Shaw, H.L., Firth, E.C., Gee, E.K. (2002b). Determination of digestible energy intake, dry matter digestibility and mineral status of grazing, New Zealand Thoroughbred yearlings. New Zealand Veterinary Journal, 50, 63-69.

Hoveland, C.S., Evers, G.W. (1995). Arrowleaf, crimson, and other annual clovers. In: Barnes RF, Miller DA, Nelson JC (eds), Forages. Volume I. An introduction to grassland agriculture, Iowa State University Press, Iowa, USA.

Lacy, J., Dear, B., Sandral, G. (2003). Persian Clover. $4^{\text {th }}$ Ed. Agfact P2.5, p 22.

Lanyon, L.E., Smith, F.W. (1985). Potassium nutrition of alfalfa and other forage legumes: temperate and tropical. In: Munson RD. (ed). Potassium in Agriculture. American Society of Agronomy, Madison, Wisconsin, USA.

Lee, C.K., Reed, K.F.M., Evans, P.M., Clarck, S.G. (1999). Register of Australian herbage plant cultivars, B. Legumes, 1 Clover, T. resupinatum var. majus Boiss. (Persian clover) cv. Morbulk. Aust J Exp Agric, 39, 505-506.

Linn, J., Kuehn, C. (1997). The effects of forage quality on performance and cost of feeding lactating dairy cows. Western Canadian Dairy Seminar 1997 Proceedings, Department of Agricultural, Food \& Nutritional Science 410 Agriculture/Forestry Centre University of Alberta Edmonton, AB, Canada.

Mariani, L., Ferrante, A. (2017). Agronomic management for enhancing plant tolerance to abiotic stresses-drought, salinity, hypoxia, and lodging. Horticulturae, 52, 1-18.

Miller, D.A. \& Reetz-JR, H.F. (1995). Forage fertilization. In: Barnes RF, Miller DA, Nelson JC (eds), Forages. Volume I. An introduction to grassland agriculture, Iowa State University Press, Iowa, USA.

Minson, D.J. (1990). Forages in Ruminant Nutrition. Academic Press, San Diego, California, USA, pp $208-229$.

Moore, J.E., Adesogan, A.T., Coleman, S.W.D., Undersander, J. (2007). Predicting forage quality. In: Barnes RF, Miller DA, Nelson JC, Collins M. (eds). Forages Volume II: The Science of Grassland Agriculture. Blackwell Publishing, Iowa, USA.

Mut, H., Gulumser, E., Dogrusoz, M.C., Basaran, U. (2017). Effect of different nitrogen levels on hay yield and some quality traits of Sudan grass and sorghum x Sudan grass hybrids. Animal Nutrition and Feed Technology, 17, 269-278.

NRC. (2001). Nutrient Requirements of Dairy Cows. $5^{\text {th }}$ Ed., National Academy of Sciences, Washington, DC, USA. 


\section{Current Trends in Natural Sciences}

Vol. 10, Issue 19, pp. 113-120, 2021

https://doi.org/10.47068/ctns.2021.v10i19.015

Current Trends in Natural Sciences (on-line)

Robinson, D.L. (1985). Potassium nutrition of forage grasses. In: Munson RD. (ed). Potassium in Agriculture. American Society of Agronomy, Madison, Wisconsin, USA.

Stace, C., Van Der Meijden, R., De Kort, I. (2010). Trifolium medium (Clover, Zigzag). Retrieved March 12, 2021, from http://nlbif.eti.uva.nl.

Stockdale, C.R. (1993). The productivity of lactating dairy cows fed irrigated Persian clover (Trifolium resupinatum). Aust J Agric Res, 44, 1591-1608.

Suttle, N.F. (2010). Mineral Nutrition of Livestock. $4^{\text {th }}$ Ed., CABI Publishing, UK.

Tekeli, A.S., Ates, E. (2002). Variations and heritability of some yield components in common vetch (Vicia sativa L.) and Persian clover (Trifolium resupinatum L.) lines. I. Herbage yield. Trakya Univ J Sci. Res Series B Natural Applied Sci, 3, 69-72.

Tekeli, A.S., Ates, E. (2003). The determination of agricultural and botanical characters of some annual clovers (Trifolium sp.). Bulg J Agric Sci, 9, 505-508.

Tekeli, A.S., Ates, E. (2006). Nutritive values of some annual clovers (Trifolium sp.) at different growth stages. Cuban J Agric Sci, 40, 93-98.

Tekeli, A.S., Ates, E. (2011). Baklagil Yem Bitkileri [Forage Legumes]. Sevil Grafik Tasarim ve Cilt Evi, Tekirdag, Turkey, pp 113-118.

Tekeli, A.S., Avcioglu, R., Ates, E. (2003). Changes in some morphological and chemical properties of Persian clover (Trifolium resupinatum L.) in relation to time and above-ground biomass. Tar Bil Derg-J Agric Sci, 9, 352-360.

Tenikecier, H.S., Ates, E. (2018). Chemical composition of six grass species (Poaceae sp.) from protected forest range in Northern Bulgaria. Asian J Applied Sci, 11, 71-75.

Tenikecier, H.S., Ates, E. (2019). Effect of altitude on morphological and nutritive characteristics of orchard grass (Dactylis glomerata L.) collected from natural flora of Ganos mountain in Thrace region, Turkey. Range Mgmt Agroforestry, 40, 286-292.

Tenikecier, H.S., Ates, E. (2020). Determination of seeding rate in the blue melilot (Melilotus caeruleus (L) Desr.) for forage yield and some quality features under subtropical conditions. Turk J Field Crops, 25, 161-167.

Tenikecier, H.S., Orak, A. (2020). Effect of different sowing times on growth attributes, forage yield and quality in three narbon vetch (Vicia narbonensis L.) genotypes at subtropical climate. Range Mgmt Agroforestry, 41, 300307. 